\title{
Antioxidant Activity of Thiosulfonate Compounds in Experiments in Vitro and in vivo
}

\author{
Liubas Nataliia $^{1(\mathbb{D})}$, Iskra Ruslana ${ }^{1(\mathbb{D})}$, Stadnytska Nataliya ${ }^{2(\mathbb{D})}$, Monka Natalija ${ }^{2(\mathbb{D})}$, \\ Havryliak Viktoriia ${ }^{2}$ (D), Lubenets Vira ${ }^{2, *(D)}$ \\ 1 Institute of Animal Biology, NAAS of Ukraine, Lviv; natalya.liubas@ gmail.com (L.N.); \\ 2 Department of Technology of Biologically Active Substances, Pharmacy and Biotechnology, Lviv Polytechnic National \\ University, Lviv, Ukraine; nataliia.y.stadnytska@lpnu.ua (S.N.); natalia.y.monka@lpnu.ua (M.N.); \\ vitahavryliak@gmail.com (H.V.); vira.i.lubenets@lpnu.ua (L.V.); \\ * Correspondence: vira.i.lubenets@1pnu.ua (L.V.);
}

Scopus Author ID 7004907171

Received: 17.05.2021; Revised: 22.06.2021; Accepted: 25.06.2021; Published: 8.08.2021

\begin{abstract}
The antioxidant activity of S-alkyl-4-aminobenzene-, S-allyl-4-aminobenzene- and 4acetylaminobenzenethiosulfonates were determined by DPPH assay in experiments in vitro to establish the relationship between their structure and activity. Among the test compounds, the highest rates of these activities were found for S-allyl-4-aminobenzenethiosulfonate (ATS), S-ethyl-4-aminobenzene thiosulfonate (ETS), and S-allyl-acetyl-aminobenzenesulfonate (AATS). These compounds were studied in experiments in vivo. The processes of lipid peroxidation (LPO) and the state of the antioxidant system in the blood of rats under the influence of thiosulfonates were studied. The use of thiosulfonate additive to feed at a concentration of $100 \mathrm{mg} / \mathrm{kg}$ body weight of animals for 21 days did not cause pathological changes in rats' blood and positively influenced antioxidant blood levels.
\end{abstract}

Keywords: antioxidant system; anti-radical activity; thiosulfonates; rats; blood.

(c) 2021 by the authors. This article is an open-access article distributed under the terms and conditions of the Creative Commons Attribution (CC BY) license (https://creativecommons.org/licenses/by/4.0/).

\section{Introduction}

The physiological condition of animals and their productivity significantly depend on adequate nutrition. Therefore, the feed must meet the specified nutrition value and aimed quality. Protecting plant products (feedstuff and food) from the action of microorganisms that produce mycotoxins, preventing fungal biofilm formation, and disinfection is an important problem.

Storage of plant products depends on various factors, such as the efficiency of storage, processes before and after harvest, moisture content, temperature, duration of storage [1-5]. During the storage of plant raw materials and feeds, lipids are most often destroy in forages due to oxidation, and toxic compounds (peroxide, aldehydes, ketones, etc.) are formed. These toxins negatively influence the growth, productivity, and viability of animals and are capable of causing several diseases.

Due to chemical changes, such processes in feed cause deterioration in the quality and storage time of raw materials and finished feed products. To prevent oxidation processes, various biologically active compounds, including antioxidants of natural or synthetic origin, are added to the feed [6-11].

The most common synthetic antioxidants used in the feed and food industries are various phenol derivatives, butylated hydroxyanisole, butylated hydroxytoluene, propyl 
gallate, and tert-butylhydroquinone. Excessive use of antioxidants can be carcinogenic and cytotoxic to the liver, kidneys, and lungs [12-14]. On the other hand, an important problem of agriculture is reducing the nutritional qualities of livestock products, primarily changes in taste and nutritional properties due to the oxidation of lipids. Therefore, it is important to find ways to overcome lipid oxidation in meat, eggs, and other foods by using biologically active substances in animal diets to increase lipid stability.

It is known that the addition of garlic powder to the diet of chickens or its combination with $\alpha$-tocopherol increases the stability of lipids in meat by elevating the content of unsaturated fatty acids, as well as stabilizing the color of meat [15]. Literature data show a positive effect of the onion extract addition as a feed additive to cows' diet. Thus, the organic sulfur compounds contained in the extracts improved the fermentation processes in the rumen by changing volatile fatty acids and reducing methane formation $[16,17]$.

The addition of onion extract containing propyl propane thiosulfonate (PTSO) as an additive to chicken feed positively affected their egg production and intestinal microbiota composition by increasing Lactobacillus spp and Bifidobacterium spp., as well as by reducing populations of Enterobacteriaceae [18-20].

Similar results were obtained in pigs. Thus, onion extract, with a high content of organic sulfur-containing compounds, added to the diet of large white piglets, had a beneficial effect on the intestinal microbiota and acted as a growth stimulant [21].

Numerous sulfur-containing compounds contained in garlic and onion extract, in particular such as allicin, alliin, and others, exhibit antioxidant activity to neutralize free radicals in reactions with 2,2-diphenyl-1-picrylhydrazyl radical (DPPH), 2,2'-azino-bis-(3ethylbenzo-thiazoline-6-sulfonic acid) with diammonium salt $\left(\mathrm{ABTS}^{+}\right)$, or with $\mathrm{Fe}$ (III) (FRAP) in vitro [22-24].

The antioxidant activity of garlic and onion extracts was also evaluated in vivo studies. Literature data indicate a protective effect of garlic extract in rats exposed to radiotherapy [25, 26]. Thus, the authors showed that the anti-inflammatory effects in mice may be related to garlic and onion extracts [27]. Also, the use of garlic and onion supplements improved the conditions of people with diseases associated with oxidative stress, such as rheumatoid arthritis or obesity [28-30].

Structural analogs of natural organic sulfur-containing compounds are S-alkyl esters of thiosulfonic acids of general formula R-S $(\mathrm{O})_{2} \mathrm{~S}-\mathrm{R}$ ', which are characterized by a wide range of biological action, which often exceeds the effectiveness of natural compounds of garlic, onion, cabbage [31, 32]. These compounds are characterized by effective antimicrobial [33-39], antithrombotic [40, 41], antitumor [42], antiviral [43] and protiparasitic effects [44].

However, synthetic sulfur-containing compounds for therapeutic and prophylactic purposes involve a preliminary study of their effects on animal bodies $[45,46]$. One of the main criteria for evaluating the possible use of new protective additives from fungal infections is to study their impact on the state of the antioxidant system in the body.

Therefore, our studies aimed to determine the antioxidant effect of thiosulfonates in vitro and their effect on the antioxidant defense system in the blood of rats in vivo. 


\section{Materials and methods}

\subsection{Anti-radical activities of thiosulfonates.}

The objects of the study were S-alkyl- and S-allylthiosulfonates: S-methyl-4aminobenzenethiosulfonate (MTS), S-ethyl-4-aminobenzenethiosulfonate (ETS), S-propyl-4aminobenzenethiosulfonate (PTS), S-allyl-4-aminobenzenethiosulfonate (ATS), S-allyl-4acetylaminobenzenethiosulfonate (AATS), synthesized at the Department of Technology of Biologically Active Substances, Pharmacy and Biotechnology of the Lviv Polytechnic National University, which have proven to be promising antimicrobial substances [31, 32, 4750].

To determine the antioxidant activities in experiments in vitro, the test compounds were reacted with the stable free radical 2,2-diphenyl-1-picrylhydrazine (DPPH). As a result of the neutralization of free radicals by thiosulfonates, discoloration of the initial DPPH solution is observed, which is fixed spectrophotometrically [51, 52].

$1.5 \mathrm{ml}$ of an ethanolic solution of DPPH with a concentration of $4.0 \mathrm{mg} / 100 \mathrm{ml}$ and $0.5 \mathrm{ml}$ of the test sample ( $0.1 \mathrm{M}$ ethanolic solution of the corresponding thiosulfonate) were mixed. After stirring, the samples were incubated for 30 minutes in the dark. For control, 0.5 $\mathrm{ml}$ of ethanol and $1.5 \mathrm{ml}$ of DPPH working solution were mixed. The absorption coefficient was measured on a Ulab 108UV spectrophotometer at a wavelength of $517 \mathrm{~nm}$. The experiment was performed in triplicate. The formula calculated the anti-radical activity:

$$
\operatorname{RSA}(\%)=100\left(\mathrm{~A}_{0}-\mathrm{A}_{1}\right) / \mathrm{A}_{0}
$$

where $\mathrm{A}_{0}$ is the optical density of a solution of DPPH in ethanol with a concentration of $4.0 \mathrm{mg}$ / $100 \mathrm{ml}$; $\mathrm{A}_{1}$ - optical density of the test sample solution.

To obtain the effective concentration of $\mathrm{IC}_{50}$ (concentration of antioxidant solution, which causes 50\% loss of DPPH activity), a series of dilutions of the initial solution of the corresponding thiosulfonate was prepared. The following formula calculated the anti-radical activity of the thiosulfonates solutions:

$$
\mathrm{ARA}=1 / \mathrm{IC}_{50}
$$

Thiosulfonates with the highest radical scavenging activity were investigated in vivo in laboratory animals.

\subsection{Experimental animals.}

The experiments in vivo were conducted on Wistar male rats with a bodyweight of 170$190 \mathrm{~g}$. This study was performed following the ethical principles of the European Convention for the protection of vertebrate animals used for experimental and other scientific purposes (Strasbourg, 2005), Law of Ukraine "On Protection of Animals from Cruel Treatment" (2006) $[53,54]$.

\subsection{Design of experiments.}

The animals were kept in the vivarium of the Institute of Animal Biology of NAAS under standard conditions of lighting, temperature, and diet. The animals were divided into four groups, each containing 5 animals: I - control, II, III, IV - experimental. All animals were clinically healthy. Control and experimental groups of animals were fed by standard pelleted 
feed for laboratory rats. Animals of the control group received $0.5 \mathrm{~cm}^{3}$ of oil to the feed once a day and experimental groups $-0.5 \mathrm{~cm}^{3}$ of oil solutions of thiosulfonates in a dose of 100 $\mathrm{mg} / \mathrm{kg}$ of body weight, in particular, group II - ETS; III - ATS; IV - AATS. Thiosulfonates' oil solutions were prepared using "Oleyna" oil (traditional refined, deodorized, certified by DSTU 4492: 2017 and ISO 14024).

The experiment lasted twenty-one days. Rats from all experimental groups were decapitated under light ether anesthesia. Blood samples were used for research. Erythrocytes were separated from plasma by centrifugation of blood at $1700 \mathrm{~g}$ for $5 \mathrm{~min}$, washed three times with cooled saline solution, and then hemolyzed with distilled water.

\subsection{Biochemical analysis.}

The object of study was erythrocytes and the blood plasma of rats. In hemolysate, the reduced glutathione (GSH) was determined by the level of thionitrophenyl anion formation due to the interaction of SH-groups of glutathione with 5,'5'-dithio-bis(2-nitrobenzoic acid). Glutathione peroxidase activity (GP, EC 1.11.1.9) was assessed by the oxidation of reduced glutathione in the presence of tertiary butyl hydroperoxide.

The activity of glutathione reductase (GR, EC 1.6.1.4.2) was determined by the rate of glutathione reduction in the presence of NADPH. Superoxide dismutase activity (SOD, EC 1.15.1.1) was fixed by the superoxide radical-mediated nitro blue tetrazolium reduction in the presence of NADH and phenazine methosulfate; catalase activity (CAT, EC 1.11.1.6) was measured by the ability of hydrogen peroxide to form a stable color complex with molybdenum salts.

In blood plasma, lipid hydroperoxides (LHP) were determined in the reaction with ammonium thiocyanate, and TBA-active products were evaluated based on the reaction between malonic dialdehyde (MDA) and thiobarbituric acid with the formation of a trimethine complex. The protein concentration was determined by the Lowry method. All measurements were performed on a spectrophotometer "Unico" 1205 (USA) [55].

\subsection{Statistical analysis.}

The obtained data were processed statistically using Microsoft EXCEL using the oneway ANOVA method. For each of the parameters, the confidence level was determined, using three gradations: $*$ - $\mathrm{p}<0.05 ; * *-\mathrm{p}<0.01 ; * * *-\mathrm{p}<0.001$, the data were considered statistically significant if $\mathrm{p}<0.05$.

\section{Results and Discussion}

\subsection{Antioxidant activity.}

For antidarical capacity (Table 1), 0.1 M solutions of MTS, ETS, PTS, ATS, and AATS can be arranged in several activities:

$\mathrm{NH}_{2}-\mathrm{C}_{6} \mathrm{H}_{4}-\mathrm{SO}_{2} \mathrm{~S}_{-} \mathrm{C}_{3} \mathrm{H}_{5}>\mathrm{CH}_{3}-\mathrm{CONHC}_{6} \mathrm{H}_{4} \mathrm{SO}_{2} \mathrm{~S}-\mathrm{C}_{3} \mathrm{H}_{5}>\mathrm{NH}_{2}-\mathrm{C}_{6} \mathrm{H}_{4}-\mathrm{SO}_{2} \mathrm{~S}-\mathrm{C}_{2} \mathrm{H}_{5}>\mathrm{NH}_{2}-\mathrm{C}_{6} \mathrm{H}_{4}-\mathrm{SO}_{2} \mathrm{~S}-\mathrm{CH}_{3}>\mathrm{NH}_{2}-\mathrm{C}_{6} \mathrm{H}_{4}-\mathrm{SO}_{2} \mathrm{~S}_{-} \mathrm{C}_{3} \mathrm{H}_{7}$

Table 1. Indexes of antioxidant activities of esters of thiosulphonic acids

\begin{tabular}{c|c|c|c} 
Compounds & RSA, \% & IC $\mathbf{5 0}, \mathbf{~ m g} / \mathbf{m l}$ & ARA \\
\hline 1 (MTS) & $18.11 \pm 0,3$ & $32.8 \pm 0,3$ & $0.031 \pm 0,02$ \\
\hline 2 (ETS) & $38.56 \pm 0,3$ & $10.35 \pm 0,2$ & $0.097 \pm 0,02$ \\
\hline 3 (PTS) & $17.30 \pm 0,4$ & $62.0 \pm 0,3$ & $0.016 \pm 0,01$ \\
\hline 4 (ATS) & $85.23 \pm 0,4$ & $6.35 \pm 0,1$ & $0.157 \pm 0,02$
\end{tabular}




\begin{tabular}{c|c|c|c} 
Compounds & RSA, \% & IC $\mathbf{5 0}, \mathbf{~ m g} / \mathbf{m l}$ & ARA \\
\hline $5(\mathrm{AATS})$ & $68.68 \pm 0,3$ & $17.0 \pm 0,2$ & $0.059 \pm 0,02$
\end{tabular}

The highest anti-radical activity was found for S-allyl-4-aminobenzene thiosulfonate (ATS), slightly lower - for S-allyl-4-acetylaminobenzene thiosulfonate (AATS), which differs in the structure of the radical in the para-position of the benzene ring. Acylation of the amino group leads to a decrease in the radical scavenging activity of thiosulfonate. The dependence of the percentage of DPPH inhibition on the concentration of the test compounds is shown in Figures 1 and 2.

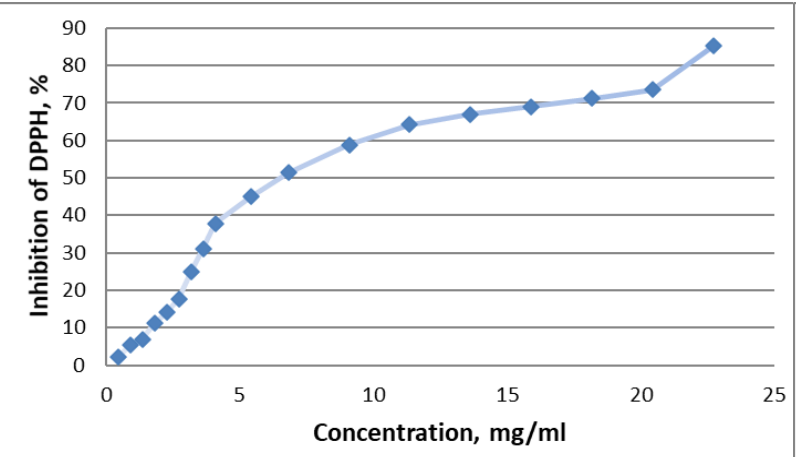

Figure 1. Effect of ATS concentration on \% of DPPH inhibition

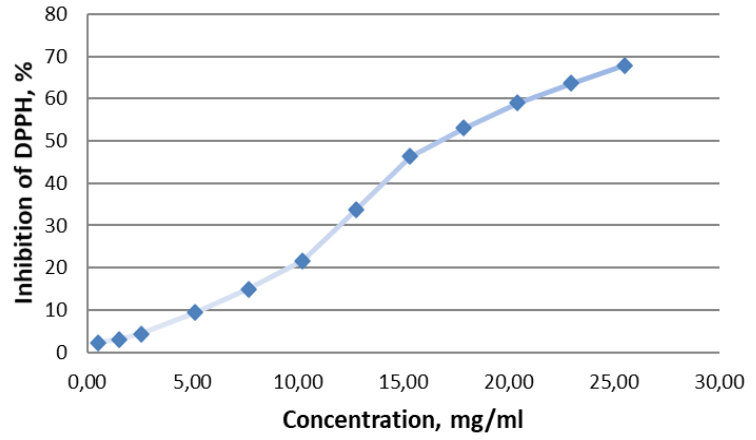

Figure 2. Effect of AATS concentration on $\%$ of DPPH inhibition

The concentration of $\mathrm{IC}_{50}$ is a value that allows us to compare the anti-radical activities of different substances. In our study, 50\% inhibition of DPPH was observed at the lowest concentration of ATS and slightly higher - for ETS and AATS (Table 1). Thus, the antioxidant activity (ARA) depends on the value of IC50 (Table 1).

The results obtained in the experiments in vitro are considered when determining promising compounds among the studied thiosulfonate. These compounds can be the potential substances for protecting feeds from pathogens during their production and storage. Therefore, in experiments in vivo, we used the most promising compounds - ETS, ATS, AATS that were added to animals' feed. The daily dose of thiosulfonates in the form of an oil solution was 100 $\mathrm{mg} / \mathrm{kg}$ of body weight of the rats.

The results of our studies indicate that the content of products of the intermediate stage of lipid peroxidation in the blood plasma of rats III $(0.35 \pm 0.05 \mathrm{OE} / \mathrm{mg})$ and IV groups $(0.23$ $\pm 0.02 \mathrm{OE} / \mathrm{mg}$ ) that received oil solutions of ATS and AATS with feed, significantly decreased compared with the control group $(0.43 \pm 0.03 \mathrm{OE} / \mathrm{mg})$ by 18.6 and $46.51 \%$, respectively.

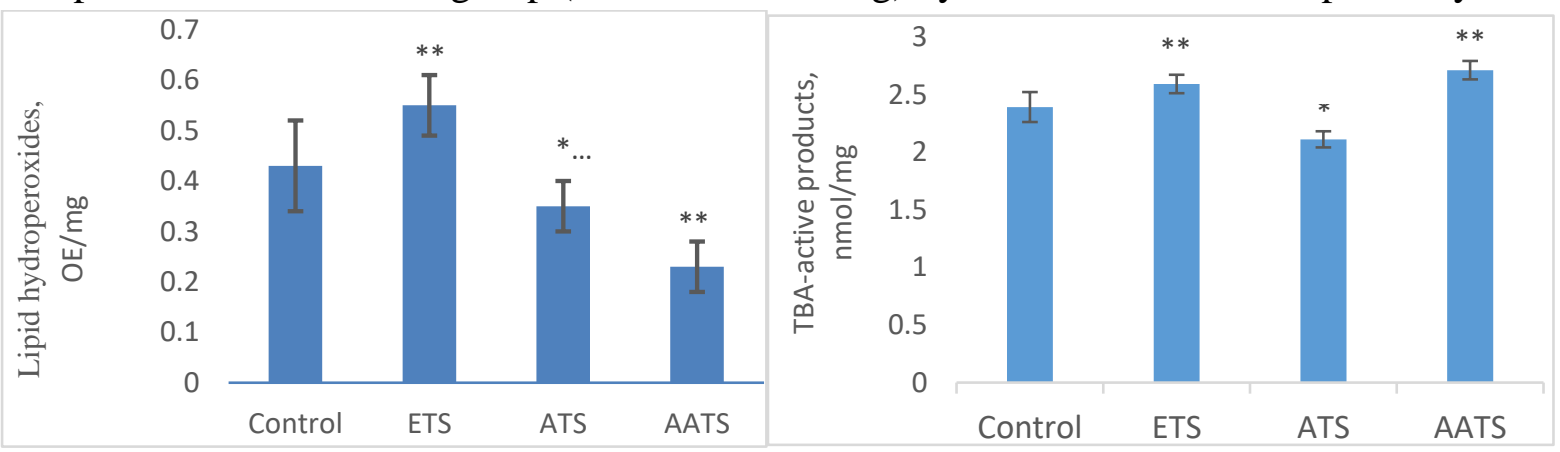

Figure 3. $\mathrm{LPH}(\mathrm{OE} / \mathrm{mg})$ and TBA-active products $(\mathrm{nmol} / \mathrm{mg})$ in the blood plasma of rats which received feed with thiosulfonates at a concentration of $100 \mathrm{mg} / \mathrm{kg}$ of body weight, $\mathrm{n}=5 ; \quad * * \mathrm{P} \leq 0.01 ; * * * \mathrm{P} \leq 0.001$ (difference are significant compared with control). 
The content of LHP in the blood plasma of animals of group II increased by $27.9 \%$ compared with controls and was $0.55 \pm 0.06 \mathrm{OE} / \mathrm{mg}$ (Figure 3). Our studies found that the content of TBA-active products in the blood plasma of groups II and IV was $2.59 \pm 0.08$ $\mathrm{nmol} / \mathrm{mg}$ and $2.71 \pm 0.08 \mathrm{nmol} / \mathrm{mg}$, respectively. This is $8.7 \%$ and $13.4 \%$ more than in the control group $(2.39 \pm 0.13 \mathrm{nmol} / \mathrm{mg})$. At the same time, their content in rats of group III was $2.11 \pm 0.07 \mathrm{nmol} / \mathrm{mg}$ and lower by $11.72 \%$ compared with the control animals (Figure 3 ).

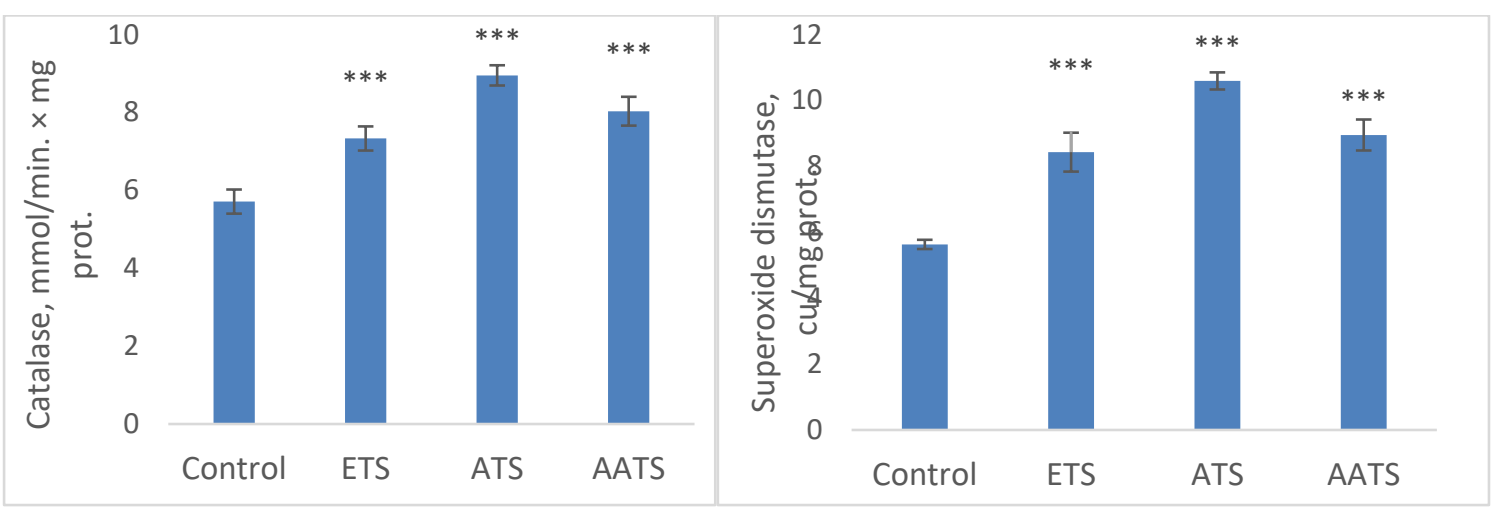

Figure 4. Activities of SOD (cu/mg prot.) and CAT (mmol/min $\times \mathrm{mg}$ prot.) in the blood plasma of rats which received feed with thiosulfonates at a concentration of $100 \mathrm{mg} / \mathrm{kg}$ of body weight, $\mathrm{n}=5 ; * * \mathrm{P} \leq 0.01$; *** $\mathrm{P} \leq$ 0.001 (difference are significant compared with control).

Our results have shown that superoxide dismutase activity in erythrocytes of rats of all experimental groups that received oil solutions ETS, ATS, AATS increased (Figure 4) by $49.7 \%$ ( $8.3 \pm 0.59 \mathrm{cu} / \mathrm{mg}$ prot. $), 88 \% \%$ (10.59 $\pm 0.26 \mathrm{cu} / \mathrm{mg}$ prot. $)$, and $59 \%$ ( $8.95 \pm 0.47 \mathrm{cu} / \mathrm{mg}$ prot.), respectively, compared with control animals $(5.63 \pm 0.4 \mathrm{cu} / \mathrm{mg}$ prot.). The highest superoxide dismutase activity was observed in the rats fed with ATS and AATS. This may explain the decrease in the concentration of lipid hydroperoxides in the plasma of animals of these groups.

Catalase activity also significantly increased in erythrocytes of rats of all experimental groups (Figure 4): by $28 \%$ - in group II ( $7.33 \pm 0.31 \mathrm{mmol} / \mathrm{min} \times \mathrm{mg}$ prot.), $57 \%$ - in group III $(8.95 \pm 0.26 \mathrm{mmol} / \mathrm{min} \times \mathrm{mg}$ prot. $), 41 \%$ - in group IV $(8.03 \pm 0.37 \mathrm{mmol} / \mathrm{min} \times \mathrm{mg}$ prot. $)$ compared with the control animals $(5.71 \pm 0.31 \mathrm{mmol} / \mathrm{min} \times \mathrm{mg}$ prot. $)$.

As can be seen from Figure 5, glutathione peroxidase activity in erythrocytes was lower in animals of groups III and IV on $14.87 \%(16.65 \pm 1.22 \mathrm{nmol} \mathrm{GSH} / \mathrm{min} \times \mathrm{mg}$ prot.) and $53.83 \%(10.88 \pm 0.62 \mathrm{nmol} \mathrm{GSH} / \mathrm{min} \times \mathrm{mg}$ prot. $)$ compared with the control group $((12.78 \pm$ $0.91 \mathrm{nmol} \mathrm{GSH} / \mathrm{min} \times \mathrm{mg}$ prot.). At the same time, the activity of this enzyme in animals of group II increased by $30.28 \%(5.9 \pm 0.81 \mathrm{nmol} \mathrm{GSH} / \mathrm{min} \times \mathrm{mg}$ prot.).

It was found that glutathione reductase activity decreased in erythrocytes of animals of all experimental groups: in group II - by $50.12 \%(0.84 \pm 0.17 \mu \mathrm{mol} \mathrm{NADPH} / \mathrm{min} \times \mathrm{mg}$ prot. $)$, group III - by $46.45 \%(0.91 \pm 0.03 \mu \mathrm{mol} \mathrm{NADPH} / \mathrm{min} \times \mathrm{mg})$ prot.), group IV - by $59.81 \%$ $(0.68 \pm 0.10 \mu \mathrm{mol} \mathrm{NADPH} / \mathrm{min} \times \mathrm{mg}$ prot. $)$ compared with the control group $(1.69 \pm 0.07$ $\mu \mathrm{mol} \mathrm{NADPH} / \mathrm{min} \times \mathrm{mg}$ prot.).

An important component of the glutathione chain of the antioxidant defense system in the body is reduced glutathione. In our studies, the content of this indicator in the blood of rats of groups II and III was higher on $22.41 \%(0.71 \pm 0.04 \mathrm{mmol} / \mathrm{L})$ and $20.34 \%(0.70 \pm 0.02$ $\mathrm{mmol} / \mathrm{L})$, respectively, higher than in the control group $(0.57 \pm 0.02 \mathrm{mmol} / \mathrm{L})$. Whereas the content of GSH in group IV did not differ from the level of the control group $(0.57 \pm 0.02$ $\mathrm{mmol} / \mathrm{L})$ (Figure 5). 

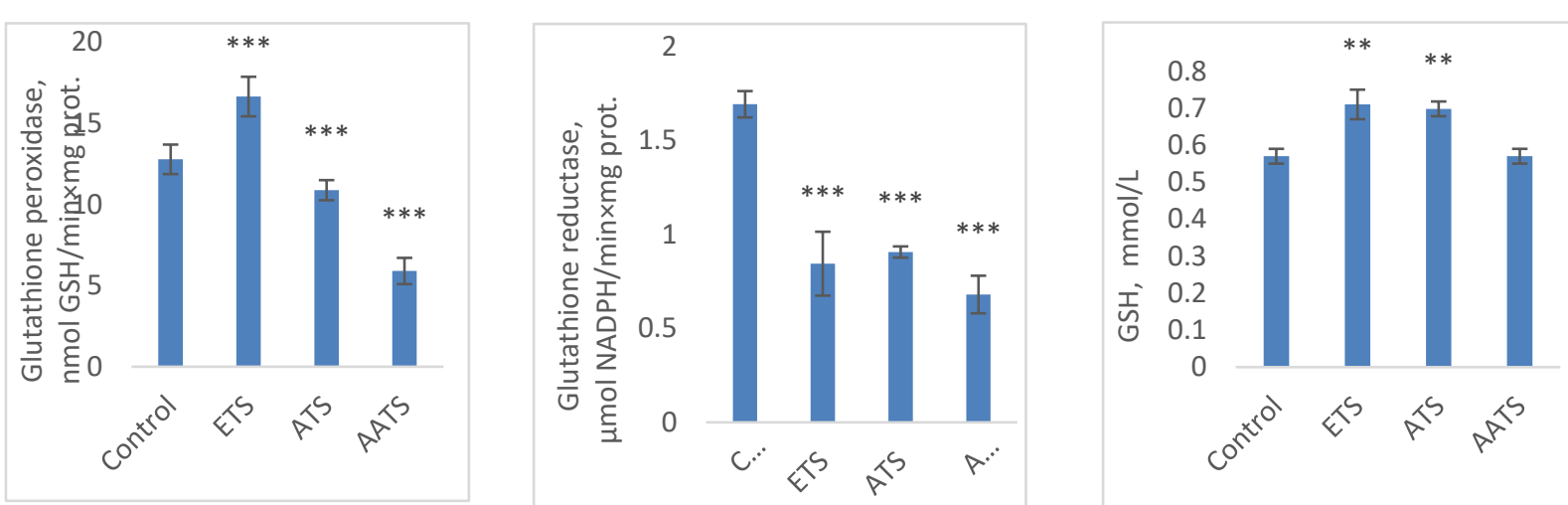

Figure 5. Activities of GP (nmol GSH/min $\times$ mg prot., GR ( $\mu$ mol NADPH/min $\times m$ g prot.), the content of GSH $(\mathrm{mmol} / \mathrm{L})$ in the blood plasma of rats which received feed with thiosulfonates at a concentration of $100 \mathrm{mg} / \mathrm{kg}$ of body weight, $\mathrm{n}=5 ; * * \mathrm{P} \leq 0.01 ; * * * \mathrm{P} \leq 0.001$ (difference are significant compared with control).

The processes of free radical oxidation constantly occur in all tissues of living organisms because they are one of the normal and necessary metabolic processes, and its acceleration or inhibition leads to certain pathologies and diseases. Our study has shown the increase of lipid hydroperoxides and TBA-active products in the blood plasma of rats that received the oil solution of ETS. Such changes indicate some stimulation of lipid peroxidation. This, in turn, leads to an increase in the activity of the main enzymes of antioxidant protection. The increase in superoxide dismutase activity confirms the activation of free radical processes in the body and the formation of superoxidation radicals $\left(\mathrm{O}_{2}^{-}\right)$. The hydrogen peroxide formed in this reaction is converted by catalase into water and oxygen molecules. The enzymes SOD and CAT act in a coordinated manner, which is confirmed in our experiment.

It is known that oxidative stress occurs in the body on the one hand due to the increased formation of free radicals, and on the other hand - to exhaustion of antioxidant protection. One of the important components of anti-radical protection is SOD activity. Results of our study have shown that the addition of oil solutions of ATS and AATS to rats feed caused a decrease in the activity of enzymes of the glutathione chain of the antioxidant defense system glutathione peroxidase and glutathione reductase on the background of high levels of SOD and catalase.

The decrease in glutathione peroxidase activity, which is observed on the background of reduced content of GSH in the blood plasma of rats of groups III and IV, can be explained by the neutralization of hydrogen peroxide by catalase.

The increase in glutathione peroxidase activity in the erythrocytes of the blood of rats receiving ETS, on the background of elevated content of reduced glutathione, indicates that long-term activation of glutathione peroxidase is possible only if high levels of intracellular GSH are maintained. It is known that intracellular reduced glutathione is a substrate for this reaction and acts as a factor necessary for the constant reduction of selenium groups located in the catalytic center of the enzyme [56].

The decrease in glutathione reductase activity in erythrocytes under the influence of ETS in animals of group II is probably due to a reduction of NADPH content [40]. The impact of thiosulfonates (ETS, ATS) on the increase in GSH concentration can be explained by the fact that during biotransformation processes in cells, thiosulfonates interact with thiol groups of amino acids. As a result of such disulfide exchange, other sulfur compounds can be formed, which can be a source for synthesizing GSH molecules. These transformations may be reflected by the following (Figure 6.) : 


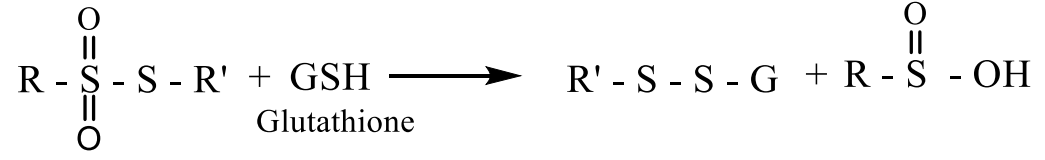

$$
\begin{aligned}
& 3 \mathrm{GSH}+\mathrm{R}-\stackrel{\mathrm{O}}{\mathrm{I}}-\mathrm{OH} \longrightarrow \mathrm{R}-\mathrm{S}-\mathrm{S}-\mathrm{G}+\mathrm{G}-\mathrm{S}-\mathrm{S}-\mathrm{G}+2 \mathrm{H}_{2} \mathrm{O} \\
& \text { Glutathione } \\
& \begin{array}{l}
\mathrm{R}=\mathrm{H}_{2} \mathrm{NC}_{6} \mathrm{H}_{4}- \\
\mathrm{R}^{\prime}=-\mathrm{CH}_{3}(\mathrm{MTS}),-\mathrm{C}_{2} \mathrm{H}_{5}(\mathrm{ETS}),-\mathrm{C}_{3} \mathrm{H}_{5} \text { (ATS), }-\mathrm{C}_{3} \mathrm{H}_{7}(\mathrm{PTS}) \\
\text { or } \\
\mathrm{R}=\mathrm{CH}_{3} \mathrm{CONHC}_{6} \mathrm{H}_{4}- \\
\mathrm{R}^{\prime}=-\mathrm{C}_{3} \mathrm{H}_{5} \text { (AATS) }
\end{array}
\end{aligned}
$$

Figure 6. Interaction of thiosulfonates with thiol groups of glutathione.

Interestingly, the elevated level of reduced glutathione in the blood of rats of groups II and III under the influence of ETS and ATS while reducing glutathione reductase activity. This tripeptide is an important intracellular antioxidant that plays a special role in maintaining cellular redox status through its participation in disulfide metabolism, providing regulation of many cell functions, including regulation of gene expression, the activity of individual enzymes, and enzyme systems. Therefore, maintaining the optimal GSH/GSSG in the cell is essential for the body's normal and vital functions. Some authors suggest that lowering the level of GSH below normal may indicate impaired cellular redox status and changes in redoxdependent gene regulation $[47,57]$.

\section{Conclusions}

The studies of the antioxidant activity of synthesized thiosulfonates have shown that the highest anti-radical activity in vitro was observed for ATS, slightly lower - for AATS and ETS. The use of thiosulfonate additive to feed in a dose of $100 \mathrm{mg} / \mathrm{kg}$ of body weight of rats for 21 days did not cause pathological changes in their blood and had a positive effect on the antioxidant status of blood parameters. Thus, further studies of the impact of thiosulfonates in the claimed dose on other body tissues are required.

\section{Funding}

This research received no external funding.

\section{Acknowledgments}

This research has no acknowledgments.

\section{Conflicts of Interest}

The authors declare no conflict of interest.

\section{References}

1. David da Silva, Carlos André Stuepp, Ivar Wendling, Cristiane Vieira Helm, Alessandro Camargo Angelo. Physiological and biochemical changes in Cedrela fissilis seeds during storage. Seed Technology • Pesq. agropec. bras. 2020, 55, https://doi.org/10.1590/S1678-3921.pab2020.v55.01309.

2. Javed, T.; Afzal, I. Impact of seed pelleting on germination potential, seedling growth and storage of tomato seed. Acta Hortic. 2020, 1273, 417-424, https://doi.org/10.17660 / ActaHortic.2020.1273.54. 
3. Qiu, Y.; Amirkhani, M.; Mayton, H.; Chen, Z.; Taylor, A.G. Biostimulant seed coating treatments to improve cover crop germination and seedling growth. Agronomy, 2020, 10 (2), 154, https://doi.org/10.3390/agronomy 10020154.

4. Zinsmeister, J., Leprince, O., Buitink, J. Molecular and environmental factors regulating seed longevity. Biochem J. 2020, 477(2), 305-323, https://doi.org/10.1042/BCJ20190165.

5. Guzzon, Filippo; Gianella , Maraeva; Juarez, Jose Alejandro Velazquez; Cano, Cesar Sanchez; E Costich, Denise. Seed longevity of maize conserved under germplasm bank conditions for up to 60 years. Ann Bot. 2021, 7, 127(6), 775-785. https://doi.org/10.1093/aob/mcab009.

6. Damini Kothari, Woo-Do Lee and Soo-Ki Kim. AlliumFlavonols: Health Benefits, Molecular Targets, and Bioavailability. Antioxidants 2020, 9, 888, 1-35, https://doi.org/10.3390/antiox9090888.

7. Antonio Sorlozano-Puerto, Maria Albertuz-Crespo, Isaac Lopez-Machado, Lidia Gil-Martinez, Juan Jose Ariza-Romero, Alba Maroto-Tello, Alberto Baños-Arjona and Jose Gutierrez-Fernandez. Antibacterial and Antifungal Activity ofPropyl-Propane-Thiosulfinate andPropyl-Propane-Thiosulfonate, Two Organosulfur CompoundsfromAllium cepa: In Vitro Antimicrobial Effect via theGas Phase. Pharmaceuticals 2021, 14, 21, https://doi.org/10.3390/ph14010021.

8. Shams, A.; Mortazavi, A.; Khosravi-Darani, K.; Bahmaei, M.; Fatemeh Seyed Reihani, S.; Dutt Tripathy, A. Effects of liposomal natural and synthetic antioxidants on oxidative stability of soybean oil. Biointerface Research in Applied Chemistry 2019, 9, 3963 - 3968. https://doi.org/10.33263/BRIAC93.963968.

9. Atta, E.; Mohamed, N.; Abdelgawad, A. Antioxidants: An Overview on the Natural and Synthetic Types. European Chemical Bulletin 2017, 6, 365, https://doi.org/10.17628/ecb.2017.6.374-384.

10. Selamoglu, Z.; Sevindik, M.; Bal, C.; Ozaltun, B.; Sen, İ.; Pasdaran, A. Antioxidant, antimicrobial and DNA protection activities of phenolic content of Tricholoma virgatum (Fr.) P.Kumm. Biointerface Research in Applied Chemistry 2020, 10, 5500 - 5506, https://doi.org/10.33263/BRIAC103.500506.

11. Kumar, S.; Bathla, A.; Rani, A.; Singh, S.; Gautam, P.; Chandra Sahi, N.; Chandra Joshi, H.; Kumar, V. Effect of microwave-assisted extraction (MAE) process on \% extraction yield, phenolic compounds and antioxidants activity of natural extract from edible fiddleheads and MAE process optimization by using response surface methodology (RSM). Biointerface Research in Applied Chemistry 2020, 10, 5689 - 5695, https://doi.org/10.33263/BRIAC104.689695.

12. Yehye, W.A.; Rahman, N.A.; Ariffin, A.; Abd Hamid, S.B.; Alhadi, A.A.; Kadir, F.A.; Yaeghoobi, M. Understanding the chemistry behind the antioxidant activities of butylated hydroxytoluene (BHT): A review. Eur. J. Med. Chem. 2015, 101, 295-312, https://doi.org/10.1016/j.ejmech.2015.06.026.

13. Murakami, Y.; Kawata, A.; Katayama, T.; Fujisawa, S. Anti-inflammatory activity of the artificial antioxidants 2-tert-butyl-4-methoxyphenol (BHA), 2,6-di-tert-butyl-4-methylphenol (BHT) and 2,4,6-tritert-butylphenol (TBP), and their various combinations. In vivo 2015, 29, 197-206.

14. Jayaprakasha, G.K.; Girennavar, B.; Patil, B.S. Radical scavenging activities of Rio Red grapefruits and Sour orange fruit extracts in different in vitro model systems. Bioresour. Technol. 2008, 99, 4484-4494, https://doi.org/10.1016/j.biortech.2007.07.067.

15. Choi, I.H.; Park, W.Y.; Kim, Y.J. Effects of dietary garlic powder and $\alpha$-tocopherol supplementation on performance, serum cholesterol levels, and meat quality of chicken. Poult. Sci. 2010, 89, 1724-1731, https://doi.org/10.3382/ps.2009-00052.

16. Martínez-Fernández, G.; Abecia, L.; Martín-García, A.I.; Ramos-Morales, E.; Denman, S.E.; Newbold, C.J.; Molina-Alcaide, E.; Yáñez-Ruiz, D.R. Response of the rumen archaeal and bacterial populations to antimethanogenic organosulphur compounds in continuous-culture fermenters. FEMS Microbiol. Ecol. 2015, 91, https://doi.org/10.1093/femsec/fiv079.

17. Abad, P.; Arroyo-Manzanares, Natalia; Gil, Lidia; García-Campaña, Ana M. Use of Onion Extract as a Dairy Cattle Feed Supplement: Monitoring Propyl Propane Thiosulfonate as a Marker of Its Effect on Milk Attributes. J Agric Food Chem. 2017, 65, 793-799, https://doi.org/10.1021/acs.jafc.6b04395.

18. Abad, P.; Arroyo-Manzanares, N.; Ariza, J.J.; Baños, A., García-Campaña, A.M. Effect of Allium Extract Supplementation on Egg Quality, Productivity, and Intestinal Microbiota of Laying Hens. Animals (Basel) 2020, 11, 41, https://doi.org/10.3390/ani11010041.

19. Amin Galavi, Hossein Hosseinzadeh, Bibi Marjan Razavi. The effects of Allium cepa L. (onion) and its active constituents on metabolic syndrome: A review. Iranian Journal of Basic Medical Sciences. 2021, 24 (1), 1-14, doi: 10.22038/ijbms.2020.46956.10843

20. Jan Borlinghaus, Jana Foerster, Ulrike Kappler, Haike Antelmann, UlrikeNoll, Martin C.H.Gruhlke, Alan J. Slusarenk. Allicin, the Odorof Freshly Crushed Garlic: A Reviewof Recent Progressin Understanding Allicin's Effectson Cell. Molecules. 2021, 26,1505. https://doi.org/10.3390/molecules26061505.

21. Sánchez, C.J.; Martínez-Miró, S.; Ariza, J.J.; Madrid, J.; Orengo, J.; Aguinaga, M.A.; Baños, A.; Hernández, F. Effect of Alliaceae Extract Supplementation on Performance and Intestinal Microbiota of GrowingFinishing Pig. Animals 2020, 10, 1557, https://doi.org/10.3390/ani10091557. 
22. Locatelli, D.A.; Nazareno, M.A.; Fusari, C.M.; Camargo, A.B. Cooked garlic and antioxidant activity: Correlation with organosulfur compound composition. Food Chem. 2017, 220, 219-224, https://doi.org/10.1016/j.foodchem.2016.10.001.

23. Jang, H.J.; Lee, H.J.; Yoon, D.K.; Ji, D.S.; Kim, J.H.; Lee, C.H. Antioxidant and antimicrobial activities of fresh garlic and aged garlic by-products extracted with dierent solvents. Food Sci. Biotechnol. 2018, 27, 219-225, https://doi.org/10.1007/s10068-017-0246-4.

24. Li, Q.; Wang, Y.; Mai, Y.; Li, H.; Wang, Z.; Xu, J.; He, X. Health Benefits of the Flavonoids from Onion: Constituents and Their Pronounced Antioxidant and Anti-neuroinflammatory Capacities. J. Agric. Food Chem. 2020, 68, 799-807, https://doi.org/10.1021/acs.jafc.9b07418.

25. Batcioglu, K.; Yilmaz, Z.; Satilmis, B.; Uyumlu, A.B.; Erkal, H.S.; Yucel, N.; Gunal, S.; Serin, M.; Demirtas, $\mathrm{H}$. Investigation of in vivo radioprotective and in vitro antioxidant and antimicrobial activity of garlic (Allium Sativum). Eur. Rev. Med. Pharmacol. Sci. 2012, 16, 47-57.

26. Wenfeng He, Yonghui Fu, Yongliang Zheng, Xiaoping Wang, Bin Liu, Junquan Zeng, Diallyl thiosulfinate enhanced the anti-cancer activity of dexamethasone in theside population cells of multiple myelomaby promoting miR-127-3p and deactivatingthe PI3K/AKT signaling pathway. Heet al. BMC Cancer. 2021, 21, 125, https://doi.org/10.1186/s12885-021-07833-5.

27. Vezza, T.; Algieri, F.; Garrido-Mesa, J.; Utrilla, M.P.; Rodríguez-Cabezas, M.E.; Baños, A.; Guillamón, E.; García, F.; Rodríguez-Nogales, A.; Gálvez, J. The Immunomodulatory Properties of Propyl-Propane Thiosulfonate Contribute to its Intestinal Anti-Inflammatory Effect in Experimental Colitis. Mol. Nutr. Food Res. 2019, 63, 1-31, https://doi.org/10.1002/mnfr.201800653.

28. Naji, K.M.; Al-Shaibani, E.S.; Alhadi, F.A.; Al-Soudi, S.A.; D'souza, M.R. Hepatoprotective and antioxidant effects of single clove garlic against CCl4-induced hepatic damage in rabbits. BMC Complement. Altern. Med. 2017, 17, 1-12, https://doi.org/10.1186/s12906-017-1916-8.

29. Moosavian, S.P.; Paknahad, Z.; Habibagahi, Z. A randomized, double-blind, placebo-controlled clinical trial, evaluating the garlic supplement effects on some serum biomarkers of oxidative stress, and quality of life in women with rheumatoid arthritis. Int. J. Clin. Pract. 2020, 74, https://doi.org/10.1111/ijcp.13498.

30. Moosavian, S.P.; Paknahad, Z.; Habibagahi, Z.; Maracy, M. The effects of garlic (Allium sativum) supplementation on inflammatory biomarkers, fatigue, and clinical symptoms in patients with active rheumatoid arthritis: A randomized, double-blind, placebo-controlled trial. Phytotherapy Research 2020, 34, 2953-2962, https://doi.org/10.1002/ptr.6723.

31. Lubenets, V.; Stadnytska, N.; Baranovych, D.; Vasylyuk, S.; Karpenko, O.; Havryliak, V.; Novikov, V. Thiosulfonates: the prospective substances against fungal infections. Fungal Infection 2019, 1-24, https://doi.org/10.5772/intechopen.84436.

32. Lubenets, V.; Vasylyuk, S.; Monka, N.; Bolibrukh, Kh.; Komarovska - Porokhnyavets, O.; Baranovych, D.; Musyanovych, R.; Zaczynska, E.; Czarny, A.; Nawrot, U.; Novikov, V. Synthesis and antimicrobial properties of 4-acylaminobenzenethiosulfoacid S-esters. Saudi Pharmaceutical Journal, 2017, 25, 266-274, https://doi.org/10.1016/j.jsps.2016.06.007.

33. Oriabinska, S.; Starovoitova, S.; Vasylyuk, V.; Novikov, V.; Lubenets, V. Ethylthiosulfanilate effect on Candida tropicalis. The Ukrainian Biochemical Journal 2017, 89, 70-76, https://doi.org/10.15407/ubj89.05.070.

34. Martirosyan, I, Pakholiuk, O., Semak, B., Lubenets, V., Peredriy, O. Investigation of wear resistance of cotton-polyester fabric with antimicrobial treatmen. Lecture Notes in Mechanical Engineering 2020, 433441, https://ouci.dntb.gov.ua/works/4EyD5O24/.

35. Martyrosian, I.A.; Pakholiuk, O.V.; Semak, B.D.; Komarovska-Porokhniavets, O.Z.; Lubenets, V.I.; Pambuk, S.A. New Technologies of Effective Protection of Textiles Against Microbiological Damage. Nanosistemi, nanomateriali, nanotehnologii. 2019, 17, 621-636, https://doi.org/10.15407/nnn.17.04.621.

36. Yeon Ho Kim, Geun Hyang Kim, Ki Sun Yoon, Shiv Shankar, Jong-Whan Rhim. Comparative antibacterial and antifungal activities of sulfur nanoparticlescapped with chitosan. Microbial Pathogenesis. 2020, 144 104178. https://doi.org/10.1016/j.micpath.2020.104178.

37. Kazuya Kanemoto, YukiSakata, Takamitsu Hosoya, and Suguru Yoshida. SynthesisofPhenoxathiins and Phenothiazines by Aryne Reactions with Thiosulfonates. Chem.Lett. 2020, 49, 593-596. doi:10.1246/cl.200132

38. Laura Ielo,Veronica Pillari, Natalie Gajic, Wolfgang Holzera, Vittorio Pace Straightforward Chemoselective Access to Unsymmetrical Dithioacetals through a Thiosulfonates HomologationNucleophilic Substitution Sequence. Chem. Commun. 2020, 1-5 DOI: 10.1039/D0CC04896H.

39. Lubenets, V.; Stadnytska, N.; Baranovych, D.; Vasylyuk, S.; Karpenko, O.; Havryliak, V.; Novikov, V. Thiosulfonates: the prospective substances against fungal infections. Fungal Infection 2019, 1-24, https://doi.org/10.19080/GJPPS.2017.03.555607. 
40. Halenova, T.I.; Nikolaeva, I.V.; Nakonechna, A.V.; Bolibrukh, K.B.; Monka, N.Ya.; Lubenets, V.I.; Savchuk, O.M.; Novikov, V.P.; Ostapchenko, L.I. The search of compounds with antiaggregation activity among S-esters of thiosulfonic acids. Ukr. Biochem. J. 2015, 87, 83-92, https://doi.org/10.15407/ubj87.05.083.

41. Bolibrukh, Kh.; Polovkovych, S.; Khoumeri, O.; Halenova, T.; Nikolaeva, I.; Savchuk, O.; Terme, T.; Vanelle, P.; Lubenets, V.; Novikov, V. Synthesis and Anti-Platelet Activity of Thiosulfonate Derivatives Containing Quinone Moiety. Sci Pharm. 2015, 83, 221-231, https://doi.org/10.3797/scipharm.1411-14.

42. R. Gonçalves Diniz Khodyuk, R. Bai, E. Hamel, E. Mariana Guimarães Lourenço, E.Guimarães Barbosa, A. Beatriz, E. dos Anjos dos Santos, D. Pires de Lima, Diaryl Disulfides and Thiosulfonates as Combretastatin A-4 Analogues: Synthesis, Cytotoxicity and Antitubulin Activity, Bioorganic Chemistry. 2020, 1-24, https://doi.org/10.1016/j.bioorg.2020.104017.

43. Kirstin Mösbauer, Verena Nadin Fritsch, Lorenz Adrian, Jörg Bernhardt, Martin Clemens Horst Gruhlke, Alan John Slusarenko, Daniela Niemeyer, Haike Antelmann. Allicin inhibits SARS-CoV-2 replication and abrogates the antiviral host response in the Calu-3 proteome. bioRxiv the preprint server for biology. 2021, 1-36, https://doi.org/10.1101/2021.05.15.444275.

44. Dmitryjuk, M.; Szczotko, M.; Kubiak, K.; Trojanowicz, R.; Parashchyn, Z.; Khomitska, H.; Lubenets, V. SMethyl-(2-Methoxycarbonylamino-Benzimidazole-5) Thiosulfonate as a Potential Antiparasitic Agent-Its Action on the Development of Ascaris suum Eggs In Vitro. Pharmaceuticals 2020, 13, https://doi.org/10.3390/ph13110332.

45. Pylypets, A. Z.; Iskra, R. Ya.; Havryliak, V. V.; Nakonechna, A. V.; Novikov, V. P.; Lubenets, V. I. Effects of thiosulfonates on the lipid composition of rat tissues. The Ukrainian Biochemical Journal, 2017, 89, 5662, https://doi.org/10.15407/ubj89.06.056.

46. Sergii Demchenko, Hanna Yeromina, Yulia Fedchenkova, Zinaida Ieromina, Vitaliy Yaremenko, Olha Vislous, Lina Perekhoda, Anatolii Demchenko.The synthesis and the antioxidant activity of 1-phenoxymethyl-4-aryl-5,6,7,8-tetrahydro-2a,4a,8a-triazacyclopenta[cd] azulene-3-carboxylic (or carbothionic) acid derivatives. Pharmacia. 2021.68(1): 251-258～DOI 10.3897/pharmacia.68.e60195

47. Zhiyuan Peng, Haolin Yin, Hui Zhang, and Tiezheng Jia. Regio- and Stereoselective Photoredox-Catalyzed Atom TransferRadical Addition of Thiosulfonates to Aryl Alkynes. Organic Letters. 2020. A-E https://dx.doi.org/10.1021/acs.orglett.0c01982.

48. Lubenets, V.I. Tiosulfonaty: syntez i vlastyvosti. Ukrainskii Khimicheskii Zhurnal, 2003, 69, 109-117.

49. Li, Q.; Wang, Y.; Mai, Y.; Li, H.; Wang, Z.; Xu, J.; He, X. Health Benefits of the Flavonoids from Onion: Constituents and Their Pronounced Antioxidant and Anti-neuroinflammatory Capacities. J. Agric. Food Chem. 2020, 68, 799-807, https://doi.org/10.1021/acs.jafc.9b07418.

50. Lubenets, V.; Karpenko, O.; Ponomarenko, M.; Zahoriy, G.; Krychkovska, A.; Novikov, V. Development of new antimicrobial compositions of thiosulfonate structure. Chemistry \& Chemical Technology 2013, 7, 119-124.

51. Pavlyuk, I., Stadnytska, N., Jasicka-Misiak, I., Wieczorek, P.P., Novikov, V. A study of the chemical composition and biological activity of extracts from wild carrot (Daucus carota L.) seeds waste. Research Journal of Pharmaceutical, Biological and Chemical Sciences. 2015, 6(2), 603-611.

52. Pavliuk, I., Stadnytska, N., Novikov, V. Investigation of the kinetics of extraction of flavonoids from hop cones meal. Eastern-European Journal of Enterprise Technologies. 2015, 5(11), 36-41.

53. Directive 2010/63/EU of the european parliament and of the council of 22 September 2010 on the protection of animals used for scientific purposes. Official Journal of the European Union L276/33. 86/609/EC. 20.10.2010.

54. Law of Ukraine "On Protection of Animals from Cruel Treatment" Vidomosti Verhovnoi Rady Ukrainy Official Bulletin of the Verkhovna Rada of Ukraine 2006, 21 February, 27.

55. Vlizlo, V.V.; Fedoruk, R.S.; Ratych, I.B. Laboratory methods of investigation in biology, stockbreeding and veterinary. 2rd ed.; Spolom: Lviv, Ukraine, 2012, 762.

56. Kotyk, B.; Iskra, R.; Slivinska, O.; Liubas, N.; Pylypets, A.; Lubenets, V.; Pryimych, V. Effects of ethylthiosulfanylate and chromium (VI) on the state of pro/antioxidant system in rat liver. The Ukrainian Biochemical Journal, 2020, 92, 78-86, https://doi.org/10.15407/ubj92.05.078.

57. Kalinina, E.V. Role of glutathione, gluthathiontransferase and glutaredoxin in regulation of redox-dependent processes. Advances in Biological Chemistry, 2014, 79, 1562-1583, https://doi.org/10.1134/S0006297914130082. 